\title{
ISCHEMIC STROKE IN A YOUNG MAN WITH MTHFR A1298C AND ACE I/D POLYMORPHISM
}

\author{
Vedat ÇíLíngíR, Aysel MİLANLIOĞLU, Temel TOMBUL \\ Yüzüncü Yıl University Faculty of Medicine Neurology Department, VAN
}

\begin{abstract}
Ischemic stroke is a leading cause of death and disability worldwide. Mutations in several candidate genes involving angiotensin-converting enzyme (ACE) and methylenetetrahydrofolate reductase (MTHFR) gene have been found to be associated with ischemic stroke. This report describes the case of a 29 year-old man who presented with sudden onset left hemiparesis and hemihipoestesia. Magnetic resonance imaging investigations showed acute ischemic infarct in the right parietal region. Mutation analysis revealed homozygout MTHFR A1298C and ACE I/D polymorphisms and laboratory invastigations showed mild hyperhomocysteinemia. No other risk factor was detected for ischemic stroke etiology.

Key Words: Ischemic stroke, etiology, genetic polymorphism, MTHFR A1298C polymorphism, ACE I/D polymorphism, genetic etiology.
\end{abstract}

\section{GENÇ YAŞ İSKEMIK İNME VAKASINDA MTHFR A1298C VE ACE I/D POLIMORFIZMI}

\section{ÖZET}

İskemik inme dünya genelinde önde gelen mortalite ve morbidite nedenlerindendir. Metilentetrahidrofolat redüktaz (MTHFR) ve Anjiotensin Converting Enzyme (ACE) genlerini de içeren bir çok genetik mutasyonun iskemik inme ile ilişkili olduğu bulunmuştur. Vaka raporumuzda ani başlayan sol hemiparezi ve hemihipoestezi nedeni ile başvuran 29 yaşındaki erkek hastayı sunuyoruz. Manyetik Rezonans görüntülemede sağ parietal bölgede multiple akut iskemik infarkt tespit edildi. Yapılan mutasyon analizinde homozigot MTHFR A1298C ve ACE I/D polimorfizmi tespit edildi. Hafif hiperhomosisteinemi dışında iskemik inme etiyolojisine yönelik yapılan araştırmalarda patoloji saptanmadı. Bu vaka homozigot MTHFR A1298C ve ACE I/D polimorfizmi birlikteliğinin iskemik inme etiyolojisinde rol oynayabileceğine ișaret etmektedir.

Anahtar Sözcükler: İskemik inme, etiyoloji, genetik polimorfizm, MTHFR A1298C polimorfizmi, ACE I/D polimorfizmi, genetik etiyoloji.

\section{INTRODUCTION}

Ischemic stroke represents almost $90 \%$ of cerebrovascular diseases, being the third cause of mortality after cardiac diseases and cancer, but the leading cause of morbidity (1).

Homocysteine plays an important role in vascular function, and its levels are determined by the interaction of genetic and environmental factors. Methylenetetrahydropholate reductase (MTHFR) is a cardinal enzyme in the folate cycle and contributes to the metabolism of homocysteine. The angiotensin-converting enzyme (ACE) converts angiotensin I to angiotensin II, which is known to be involved in vascular hypertrophy, vasoconstriction, and atherosclerotic processes.

In this report we describe the case of a 29 year-old man who presented with multiple acute ischemic infarcts that have revealed ACE ID and homozygous MTHFR A1298C polymorphism and hyperhomocysteinaemia after investigation.

\footnotetext{
Corresponding author: Vedat Çilingir, MD. Yüzüncüyıl University Faculty of Medicine, Department of Neurology, Van, TURKEY

Telephone: +90 04322150470 E-mail: vedatcilingir@yahoo.com

Received: $20.12 .2013 \quad$ Accepted: 10.01 .2014

This article should be cited as following: Çilingir V, Milanlığlu A, Tombul T. Ischemic stroke in a young man with MTHFR A1298C and ACE I/D polymorphism. Turkish Journal of Cerebrovascular Diseases 2014; 20 (2): 73-76. doi:10.5505/tbdhd.2014.96658.
} 


\section{CASE}

A 29 year-old man without history of neurological or systemic diseases was admitted for acute cerebrovascular disease presented with sudden onset of left hemiparesis and hemihipoestesia. On admission, his blood pressure was $125 / 60 \mathrm{~mm} \mathrm{Hg}$, and no carotid bruit or abnormal heart sounds were heard. Neurological examination demonstrated mild left-side weakness and left-side hemihipoestesia, cranial nerves were all intact, speech was fluent without aphasia or dysarthria, reflexes were $2 / 4$ throughout, and his gait did not reveal any ataxia. Magnetic resonance imaging investigations showed multiple acute ischemic infarct in the right parietal region (Figure 1).

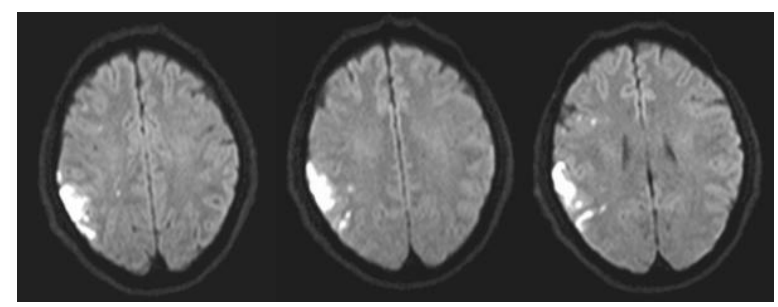

Figure 1. Diffusion-weighted magnetic resonans imaging showed patchy early subacute infarctions in right parietal lobe.

Traditional risk factros for ischemic stroke, hypertension, hyperlipidemia, cardiac pathology, cigarette smoking, obesity, alcohol consumption were all negative. A complete blood count and metabolic panel were normal. Laboratory work up including prothrombin time, activated partial thromboplastin time, fibrinogen, protein $\mathrm{C}$, protein $\mathrm{S}$, antithrombin III activity, levels of vitamin B12 and folate, peripheral blood smear were all within the normal limits. Anticardiolipin antibodies, lupus anticoagulant antibodies, vasculit markers were negative. Plasma homocysteine level was 13,3 $\mu \mathrm{mol} / \mathrm{L}$. There was no reported family history of coagulation disorder of any kind. Magnetic resonance venography of the brain revealed no stenosis. Magnetic resonance angiography showed no vascular malformation, aneurysm or proximal stenosis (Figure 2).

Carotid and vertebrobasilar arteries duplex imaging showed no plaques or stenosis. Electrocardiogram and 24-hour holter monitoring showed normal sinus rhythm. Transthoracic echocardiogram did not show any valvular lesion or intracardiac thrombus. A transesophageal

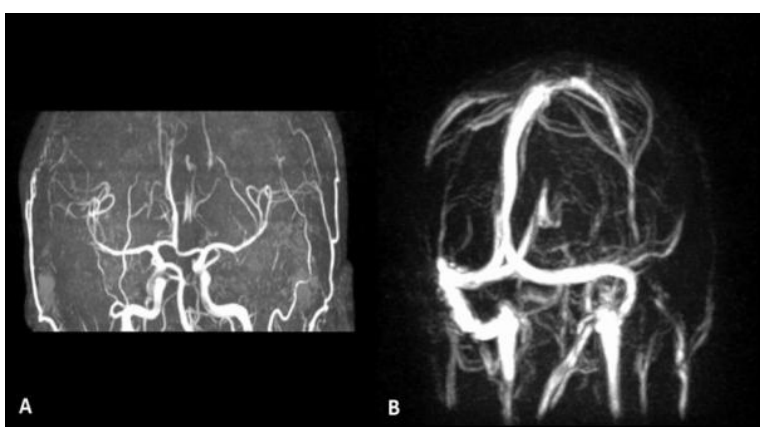

Figure 2. Magnetic resonance angiogram arterial phase A and venous phase $B$.

echocardiogram with bubble study performed after admission was negative for any patent foramen ovale, atrial septal defect, thrombus, or right-to-left shunt. Genetic analysis revealed that the patient has homozygous MTHFR A1298C and ACE ID polymorphism. No mutations were found for Factor V Leiden, Factor V H1299R, Factor XIII V34L, Glikoprotein IIIa L33P, Protrombin G20210A, b-fibrinogen 455G/A, Plasminogen activator inhibitor type $14 \mathrm{G} / 5 \mathrm{G}$, MTHFR C677T, Apo-lipoprotein BR3500Q, or Apolipoprotein E.

He was firstly treated with subcutaneous low molecular weight heparin than it was switched to oral anticoagulation. The patient was discharged with only minor neurologic deficits (slight leftsided hemihipoestesia). He remains well with no recurrence of stroke during the follow-up in the past 6 months

\section{DISCUSSION}

Evidence from genetic association studies indicate that genetic predisposition, in addition to such recognized risk factors as hypertension, smoking, diabetes, obesity, and advanced age, contributes to the development of stroke (2).

MTHFR is an important enzyme in modulation of plasma homocysteine status by converting it into methionine. It catalyzes the biologically irreversible reduction of 5,10Methylenetetrahydropholate. Human MTHFR gene is localized to chromosome 1 p36.3 and coded MTHFR enzyme which consists of 563 amino acids. Mutation within the gene coding for MTHFR, A1298C, results in reduced catalytic activity of the enzyme (3) and may be associated with elevated plasma homocysteine levels.

The degree of prothrombotic risk associated with the MTHFR A1298C mutation is controversial 
but association between plasma levels of total homocysteine (tHcyt) and stroke has been widely documented by multiple authors in different populations (4).

Hyperhomocysteinemia is defined as the presence of an abnormally elevated concentration of plasma or serum tHcyt levels which depends on interaction between genetic polymorphisms of enzymes in the folate metabolism pathway and other acquired factors, such as vitamin B12, vitamin B6 or folate deficiency.

The proposed mechanisms by which hyperhomocysteinemia causes vascular complications are: the induction of atherosclerosis by homocysteine's interaction with lipids; the induction of vascular endothelial dysfunction by reducing the bioavailability of endothelial nitric oxide synthetase and altering endothelial cell function by up-regulating the expression and secretion interleukin 8, hence promoting leukocyte recruitment (5). A previous overview showed that the effects were greatest in regions with low dietary folate consumption (6).

Meta-analysis performed by Homocysteine Studies Collaboration found that 25\% elevation (about $3 \mu \mathrm{mol} / \mathrm{L}$ ) in plasma tHcyt was associated with about a $10 \%$ higher risk of cardiovascular events and a 20\% higher risk of stroke (7).

Folic acid with vitamins B6 and B12 has been shown to be effective in reducing elevated homocysteine levels, but a recent review found no evidence to suggest that homocysteine-lowering interventions in the form of supplements of vitamins given alone or in combination should be used for preventing cardiovascular events (8).

The rennin-angiotensin-aldosterone system (RAAS) plays an important role in regulating blood pressure, and water and salt balance. ACE, a key enzyme in the RAAS, catalyses the conversion of inactive angiotensin I to active angiotensin II and inactivates bradykinin resulting in decreased tissue perfusion, vascular smooth muscle cell growth. ACE gene is located on chromosome 17q23, where an insertion/deletion polymorphism in intron 16 has been identified. This polymorphism is based on the presence (insertion, I) or absence (deletion, D) of a 287-bp DNA fragment (9).

There is evidence that allele I of ACE gene is associated with lower ACE levels, whereas D allele is associated with increased ACE activity (10).
Numerous studies have reported a positive or null relation between the $\mathrm{D}$ allele and cerebrovascular diseases, and findings have been controversial.

Markoula et al. indicate that I/D polymorphisms may have a role in stroke development, as far as gender is concerned. They found a statistically significant decrease in the incidence of II genotype in females with stroke compared with males with stroke, whereas the DD genotype (and the D allele) was only moderately more common among females with stroke compared with males with stroke. The results indicate that I/D polymorphisms may have a role in stroke onset, in respect to gender, with a possible favourable effect of II genotype in females (11).

According to the meta-analysis results performed by Zhang, the D allele of ACE I/D polymorphism is a low-penetrance susceptibility marker of ischemic stroke (9).

Our patient has the ACE I/D genotype although one D allel is not as strong as homozygous $\mathrm{D}$ genotype as regards ischemic stroke risk factor it may contribute to tromboembolism. He also has mildly elevated tHcyt levels and MTHFR 1298 CC genotype, no other etiologic risk factor was detected.

Conceivably, heterozygous ACE ID and homozygous MTHFR A1298C polymorphisms are preadventure to yield to ischemic stroke one by one but when they are together the stroke possibility may be increased. We suggest that investigating genetic etiology may impress treatment options and prevent stroke recurrence in ischemic stroke patients.

\section{REFERENCES}

1. Lloyd-Jones D, Adams RJ, Brown TM, et al. American Heart Association Statistics Committee and Stroke Statistics Subcommittee, Executive summary: heart disease and stroke statistics - 2010 update: a report from the American Heart Association. Circulation 2010, 121(7):948-954.

2. Sharma P Genes for ischaemic stroke: strategies for their detection. J Hypertens 1996 14: 277-285.

3. Rosenblatt DS. Methylenetetrahydrofolate reductase. Clin Invest Med 2001;24:56-59.

4. Boushey CJ, Beresford SA, Omenn GS et al. A quantitative assessment of plasma homocysteine as a risk factor for vascular disease. Probable benefits of increasing folic acid intakes. JAMA 1995; 274: 1049-1057.

5. Almawi WY, Khan A, Al-Othman SS Case-control Study of Methylenetetrahydrofolate Reductase Mutations and Hyperhomocysteinemia and Risk of Stroke. Journal of Stroke and Cerebrovascular Diseases, Vol. 18, No. 5 (September- 
October), 2009: pp 407-408.

6. Holmes MV, Newcombe P, Hubacek J, et al. Effect modification by population dietary folate on the association between MTHFR genotype, homocysteine, and stroke risk: a meta-analysis of genetic studies and randomised trials Lancet 2011; 378: 584-94

7. Homocysteine Studies Collaboration. Homocysteine and risk of ischemic heart disease and stroke: a meta-analysis. JAMA 2002;288:2015-22.

8. Sirachainan N, Tapanapruksakul $\mathrm{P}$, Visudtibhan $\mathrm{A}$, et al. Homocysteine, MTHFR C677 T, vitamin B12, and folate levels in Thai children with ischemic stroke: a case-control study. J Pediatr Hematol/Oncol 2006;28(12):803-8.
9. Zhang Z, Xu G, Liu D, et al. Angiotensin-Converting Enzyme Insertion/Deletion Polymorphism Contributes to Ischemic Stroke Risk: A Meta-Analysis of 50 Case-Control Studies PLOS ONE October 2012 Volume 7 | Issue 10 | e46495.

10. Ay C, Bencur P, Vormittag R, et al. The angiotensinconverting enzyme insertion/deletion polymorphism and serum levels of angiotensin-converting enzyme in venous thromboembolism. Data from a case control study. Thromb Haemost 2007; 98: 777-782.

11. Markoula S, Giannopoulos S, Kostoulas C, et al. Gender association of the angiotensin-converting enzyme gene with ischaemic stroke Journal of Renin-Angiotensin-Aldosterone System 2011 12: 510-515. 